\title{
Effect of the Kuroshio intrusion on the chlorophyll distribution in the southern East China Sea during spring 1993
}

\author{
GWO-CHING GONG, ${ }^{*}$ FUH-KWO SHIAH, $†$ KON-KEE LIU, †† \\ WEN-SSN CHUANG ${ }^{\dagger}$ and JENG CHANG $\S$
}

(Received 18 July 1995; in revised form 5 February 1996; accepted 28 March 1996)

\begin{abstract}
In order to assess the effect of the Kuroshio intrusion on phytoplankton biomass in the southern East China Sea nor th of Taiwan, chlorophyll $a$ distributions observed before and after the recession of the seasonal Kuroshio intrusion were compared. Weekly hydrographic surveys and moored current meter data showed that the Kuroshio intruded onto the shelf under the prevailing northeasterly in early April 1993, and it retreated in early May 1993 shortly after the cessation of the northeasterly. The chlorophyll $a$ distribution showed an eminent increase with a concentric distribution pattern, which was obviously related to the re-emergence of the year-round upwelling at the shelf break northeast of Taiwan. Strengthened upwelling was evidenced by a concomitant increase of nitrate concentration in the subsurface water near the shelf break. The mean value of the euphotic zone integrated chlorophyll $a$ concentration in the normal upwelling area increased from 16 to $36 \mathrm{mg} \mathrm{m}^{-2}$ after the Kuroshio withdrawal. The high chlorophyll $a$ concentration in the upwelling region was shown associated with the high primary productivity measured in the following year, May 1994. The euphotic zone integrated chlorophyll a concentration and primary production in the upwelling water were found to be $33 \mathrm{mg} \mathrm{m}^{-2}$ and $1540 \mathrm{mgC} \mathrm{m}^{-2} \mathrm{~d}^{-1}$, respectively. The higher chlorophyll and primary production was apparently the results of ample nutrient supply from the upwelling. At the same time, very high primary production was found in the mainland China coastal water with a value of $1900 \mathrm{mgC} \mathrm{m}^{-2} \mathrm{~d}^{-1}$ corresponding to a dinoflagellate bloom with population densities exceeding $1 \times 10^{4}$ cells $\mathrm{l}^{-1}$. The Kuroshio water, on the other hand, has the lowest primary production value of $420 \mathrm{mgC} \mathrm{m}^{-2} \mathrm{~d}^{-1}$. Copyright (C) 1996 Elsevier Science Ltd
\end{abstract}

\section{INTRODUCTION}

Upwelling systems have always been an attractive site for oceanographic studies due to their eminent biological, physical and chemical signals. In the southern East China Sea northeast of Taiwan, the impingement of the Kuroshio onto the continental shelf induces upwelling in association with a subsurface countercurrent landward of the impinging

\footnotetext{
*Department of Oceanography, National Taiwan Ocean University, Keelung, Taiwan, Republic of China. †Institute of Oceanography, National Taiwan University, Taipei, Taiwan, Republic of China. $\ddagger$ Global Change Research Center, National Taiwan University, Taipei, Taiwan, Republic of China. §Institute of Marine Biology, National Taiwan Ocean University, Keelung, Taiwan, Republic of China.
} 


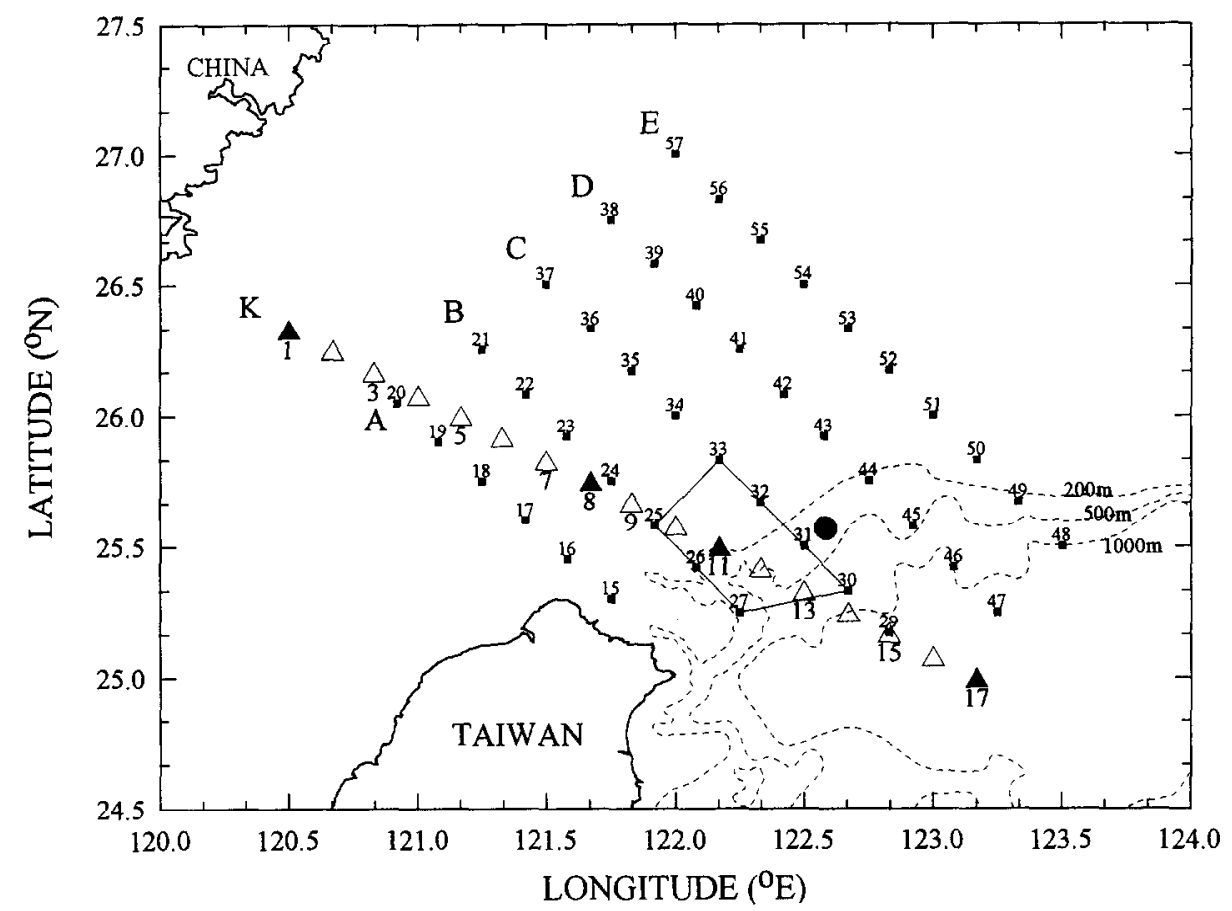

Fig. 1. Map of the southern East China Sea showing sampling stations. Mooring station ( $)$; transect $\mathrm{K}$ stations $(\Delta)$; primary productivity stations $(\boldsymbol{\Delta})$. See also Table 1 for cruises information. The upwelling area is within the stations connected by solid lines.

current (Chuang et al., 1993). A dome-shaped pool of upwelled Kuroshio subsurface water (UKSW) has been shown present at the shelf break northeast of Taiwan all year round (Gong, 1992; Liu et al., 1992a; Gong et al., 1995a). The outcropping of the UKSW often results in a cold patch which can be found most of the time in an area bounded by stations 25, 26, 27, 30, 31, 32 and 33 in Fig. 1 (Gong et al., 1992; Lin et al., 1992). High chlorophyll concentrations have been observed around this region (Chen, 1992; Gong et al., 1993, 1995b).

The outcropping of the UKSW is sometimes suppressed by outflowing of shelf water under persistent southwest monsoon (Gong et al., 1992). In the present study, evidence shows that the upwelling can be suppressed or displaced by the shelfward intrusion of the Kuroshio surface waters (KSW) which intrudes onto the shelf slope in mid-October and retreats off the shelf in May (Sun, 1987; Lin et al., 1992; Tang and Yang, 1993; Chuang and Liang, 1994). The mechanism of intrusion is not well understood but has been linked to several plausible processes, such as Ekman drift of the KSW, cooling of shelf water, suppression of the Kuroshio branch current in the Taiwan Strait and reduced stratification, all under the influence of the northeast monsoon (Chao, 1991; Chern and Wang, 1992; Liu et al., 1992b; Chern and Wang, 1994; Chuang and Liang, 1994). When the northeast monsoon subsides, the Kuroshio quickly recedes from the shelf probably due to the rcsumption of the Kuroshio branch current through the Taiwan Strait (Wang and Chern, 1988, 1989; Chao, 1991).

A water mass that usually occupies the inner shelf northwest of Taiwan during the 
northeast monsoon period is the low-salinity and nutrient-laden mainland China coastal water (CCW; Gong, 1992; Liu et al., 1992b; Gong et al., 1995a). The interaction among these water masses inevitably will alter the availability of nutrients, influence the rate of carbon fixation, and finally determine the phytoplankton biomass distribution.

The primary productivity of the southern East China Sea has been investigated by a few snapshot studies (Hung et al., 1980; Fei et al., 1987), and a general pattern of chlorophyll distribution has been reviewed by Guo (1991). However, they provided little insight into the relationships among physical forcing, hydrography and the variability of primary productivity and chlorophyll concentrations in this area. The major purpose of this paper is to show, from a series of spring cruises in 1993, how nutrient (nitrate) and chlorophyll distribution patterns in the southern East China Sea north of Taiwan changed in response to the cessation of the shelfward intrusion of the KSW. Primary productivity in the three water masses of the southern East China Sea north of Taiwan was also measured at the same time in 1994 to gain more insight about the relationship between nitrate and chlorophyll distribution.

\section{MATERIALS AND METHODS}

\section{Study area and sampling}

The study was performed in the southern East China Sea north of Taiwan (Fig. 1) as part of the multidisciplinary KEEP (Kuroshio Edge Exchange Processes) program. Four weekly cruises (cruises 352A-D) were conducted on board the R/V Ocean Researcher I during 14 April to 15 May 1993 to investigate the biogeochemical responses to the change of shelf conditions during the change of the prevailing wind. Transects B-E and A-E were occupied on the first and the third cruises, respectively, and transect $\mathrm{K}$ was occupied on the second and the fourth cruises (Fig. 1). The first and the third cruises were used to examine the effect of the Kuroshio intrusion on the phytoplankton distribution, because their areal coverages were more suitable to study the change in distribution pattern. An additional cruise (cruise 386) was conducted along transect K in May 1994 to investigate the primary productivity in different nutrient regimes. Table 1 lists the detailed information about the cruises. Water samples were collected from a SeaBird CTD-General Oceanic Rosette assembly with 2.5 -liter Teflon-coated Go-Flo bottles. Irradiance was measured with a $2 \pi$ quantum scalar irradiance meter (L185B; Licor Inc.) on cruise 386. The depth of the euphotic zone was defined as the level of $1 \%$ of the surface light. The depths of the euphotic zone for the earlier cruises $352 \mathrm{~A}$ and $352 \mathrm{C}$ were calculated from the pigment (chlorophyll $a+$ phaeopigment) profile by using the relationship between the euphotic

Table 1. Cruise information (see also Fig. 1 for the location of transect)

\begin{tabular}{lccc}
\hline Cruise no. & Date & Transect & No. of station \\
\hline 352A & $04.14-04.191993$ & B, C, D, E & 36 \\
352B & $04.21-04.291993$ & K & 17 \\
352C & $05.01-05.051993$ & A, B, C, D, E & 42 \\
352D & $05.07-05.151993$ & K & 17 \\
386 & $05.04-05.101994$ & K & 17 \\
\hline
\end{tabular}


depth and the mean pigment concentration described in Morel (1988). The relationship was shown applicable in our study area based on the recent results (Gong and Liu, 1995).

\section{Mooring observations}

A mooring with current meter (Aanderaa RCM-7) anchored at the depth of $110 \mathrm{~m}$ was deployed on the slope northeast of Taiwan (Fig. 1) from 28 March to 2 August 1993. The sampling interval was set at $30 \mathrm{~min}$. The water depth of the shelf break is about $120 \mathrm{~m}$ (see Fig. 2), so the meter can effectively measure the cross-slope current.

\section{Nutrients, chlorophyll a and phytoplankton composition}

Water samples for nutrients analyses were subsampled with clean 100-ml polypropylene bottles and were frozen immediately with liquid nitrogen. Nitrate was analyzed with a selfdesigned flow injection analyzer and was reduced to nitrite with a cadmium wire, which was activated with a copper sulfate solution (Gong, 1992). Chlorophyll $a$ concentrations $\left(\mathrm{Chl} a ; \mathrm{mg} \mathrm{m}^{-3}\right.$ ) were obtained from the calibrated in-situ fluorescence of the Sea Tech fluorometer mounted on the CTD. The relationship between in-situ fluorescence and measured acetone extracted Chl $a$ in seawater of the study area had been reported by Gong et al. $(1993,1995 \mathrm{~b})$. They showed that the relationship between in-situ fluorescence and measured acetone-extracted Chla was very stable both temporally and spatially. Therefore, it is reasonable to use the calibrated in-situ fluorescence to present Chla in the present study. Euphotic zone integrated Chla concentrations were calculated by trapezoidal integration. The samples for phytoplankton species determination were preserved with acidic Lugol's solution (Throndsen, 1978) and examined using a Nikon microscope (Optiphot-2) at $100 \times$.

\section{Primary productivity}

Primary productivity (PP) experiments on cruise 386 were conducted by the ${ }^{14} \mathrm{C}$ assimilation method (Parsons et al., 1984; Shiah et al., 1995). Two light and one dark 250$\mathrm{ml}$ clean polycarbonate bottles (Nalgene) were filled with water which was pre-screened through $200-\mu \mathrm{m}$ woven mesh (Spectrum) to remove large organisms and particles and inoculated with $10 \mu \mathrm{Ci} \mathrm{NaH}{ }^{14} \mathrm{CO}_{3}$. Incubation bottles were all pre-washed by soaking in a $10 \% \mathrm{HCl}$ solution overnight and rinsing at least three times with Milli-Q water and also rinsed with sample waters three times before use. One clear bottle was immediately filtered as the time zero control. PP samples were incubated on deck from dawn to down and cooled with running scawatcr. Duplicatc light bottles for a given depth werc covered with different layers of nylon stockings to simulate the degree of the light penetration at that particular depth. The correlation between layers of nylon stockings $(N)$ and $I_{z} / I_{0}$ (the ratio between light intensity at depth $z$ and that at sea surface) previously determined at the laboratory was $N=-3.93 \times \ln \left(I_{z} / I_{0}\right), n=10, R^{2}=0.99$.

Following retrieval, the bottles were stored in the dark and processed immediately. From each light bottle, $0.25-\mathrm{ml}$ was taken and transferred to a $15-\mathrm{ml}$ scintillation vial containing $2.5 \mathrm{ml}$ of Milli-Q water and $0.25 \mathrm{ml}$ of ethanolamine, and then $10 \mathrm{ml}$ of scintillation cocktail (Ultima Gold) was added. This was to determine the total activity of $\mathrm{H}^{14} \mathrm{CO}_{3}$ in the sample. The water samples were then filtered through $25-\mathrm{mm} \mathrm{GF} / \mathrm{F}$ filters. 

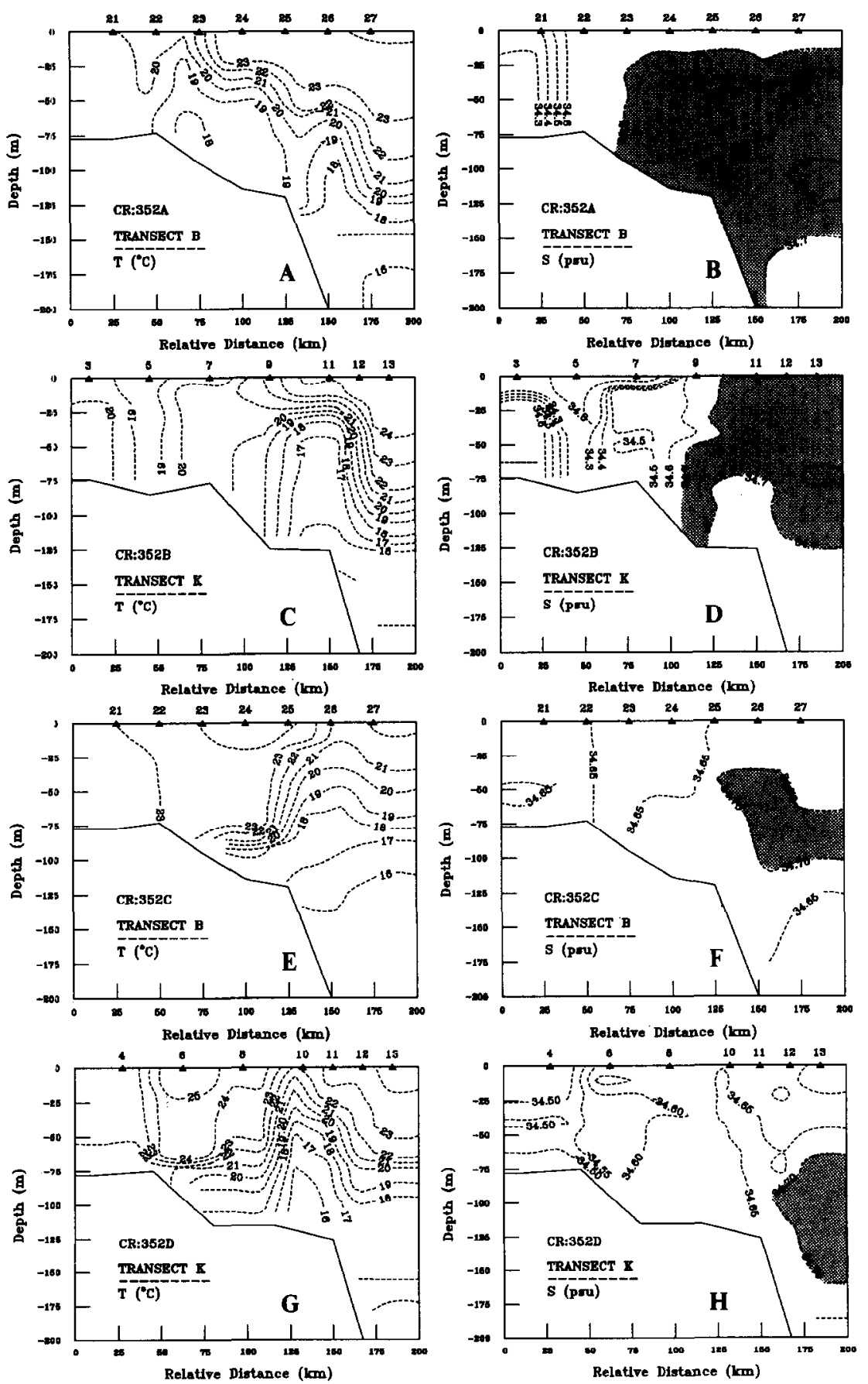

Fig. 2. Sections of temperature and salinity during cruises $352 \mathrm{~A}-\mathrm{D}$. See also Table 1 and Fig. 1. 
Pumping pressure was maintained below $100 \mathrm{mmHg}$ to prevent the possible damage of cells. The filters then were placed in scintillation vials and stored in the dark. After being returned to the laboratory, $0.5 \mathrm{ml}$ of $0.5 \mathrm{M} \mathrm{HCl}$ was added to the vials containing filters, which were left open under the hood at room temperature overnight. The time zero sample, total activity and incubated samples were counted in a liquid scintillation counter (PACKARD 1600) after the addition of $10 \mathrm{ml}$ scintillation cocktail to the vials.

\section{RESULTS}

The weekly hydrographic surveys in the spring of 1993 in the study area provided a good opportunity to study the Kuroshio interaction with the East China Sea shelf during a transition period of the KSW intrusion. The sections of temperature and salinity along transects $\mathrm{B}$ and $\mathrm{K}$ from the four consecutive weekly cruises clearly depict the withdrawal of the KSW from the shelf to the slope (Fig. 2).

Shelfward intrusion of the KSW northeast of Taiwan was observed on the first cruise in mid-April 1993. The salty KSW (>34.7 psu) occupied most of the upper water column on the outer shelf and slope (Fig. 2B). This water formed a rather thick surface mixed layer of $20-50 \mathrm{~m}$ with a temperature around $23^{\circ} \mathrm{C}$ (Fig. $2 \mathrm{~A}$ ). On the following cruise, the highsalinity water (indicated by the stippled area in Figs $2 \mathrm{D}, 2 \mathrm{~F}$ and $2 \mathrm{H}$ ) withdrew gradually from the shelf to the slope. While the KSW retreated, the UKSW started to dome up at the shelf break, which signaled upwelling. Even at the peak of KSW intrusion, the upwelling water still existed at greater depth (Fig. 2A). However, while the upward movement of cold water was suppressed by the KSW, the upwelling was not detectable at the sea surface (Figs $2 \mathrm{~A}$ and $3 \mathrm{~A}$ ). Part of the upwelled water might be pushed onto the shelf and formed a pool of cold salty water near the bottom between stations 22 and 23 (Fig. 2A). On the third cruise (352C), a well-developed upwelling dome existed near the shelf break between stations 26 and 27 , with cool water $\left(22^{\circ} \mathrm{C}\right)$ outcropping at the surface (Fig. $2 \mathrm{E}$ ).

The horizontal distributions of various water types before and after the recession of the KSW are illustrated by the sea surface temperature and salinity contours observed on the first (352A) and the third (352C) cruises (Fig. 3). On the first cruise, the KSW with higher temperature $\left(23^{\circ} \mathrm{C}\right.$ isotherm $)$ and salinity $(>34.7 \mathrm{psu})$ occupied the entire study area from the mid-shelf to the slope north of Taiwan (Figs 3A and 3B), indicating the extent of the Kuroshio intrusion. On the third cruise, a pool of cold water bounded by the $22^{\circ} \mathrm{C}$ isotherms existed around the shelf break north of Taiwan (Fig. 3C), indicating that the intruding KSW gave way to the upwelled UKSW. However, a band of high-salinity water ( $>35.7 \mathrm{psu}$ ) still occupied the outer shelf east of the upwelling region (Fig. 3D), suggesting that the KSW did not retreat entirely from the shelf but its main axis had shifted eastward.

A cold-water front on the inner shelf ncar stations 37 and 38 was observed on both cruises (Figs $3 \mathrm{~A}$ and $3 \mathrm{C}$ ). The salinity of this cold water was significantly lower than that of the UKSW (Figs 3B and 3D), suggesting it contained significant portion of the CCW which dispersed from the northwest.

The current meter data support the view that the observed temperature and salinity distribution was caused by a change in the Kuroshio flow pattern (Fig. 4). The Kuroshio intrusion started in mid-October 1992, a month after the onset of the northeast monsoon.

Chuang and Liang (1994) showed that the cross-slope current did not remain constant but fluctuated under wind modulation in accordance with the synoptic weather pattern. During late March to mid-April 1993, an on-shelf current with a maximal speed of $50 \mathrm{~cm}$ 
$\mathrm{s}^{-1}$ at the depth of $110 \mathrm{~m}$ was observed under the prevailing northeast monsoon (Fig. 4). In mid-April (during cruise 352A), the wind slackened and started to fluctuate in its direction. Ten days later (during cruise 352B), the cross-slope current reversed abruptly and marked the end of the KSW intrusion. The sudden current-reversal could have been caused by the out-flow of Taiwan Strait water associated with the resumption of the Kuroshio branch current (Wang and Chern, 1988, 1989; Chao, 1991). Subsequently, the current weakened and fluctuated with the mean velocity of less than $15 \mathrm{~cm} \mathrm{~s}^{-1}$.

The spatial distribution of nitrate concentrations at $50 \mathrm{~m}$ depth of cruises $352 \mathrm{~A}$ and $352 \mathrm{C}$ were totally different (Figs 5A and 5B). All the isopleths observed on cruise 352C located more southeastward than those of cruise $352 \mathrm{~A}$. The concentric nitrate isopleths found on cruise $352 \mathrm{C}$ clearly marked the position of the upwelling (Fig. 5B). The corresponding distributions of euphotic zone integrated Chla (ICHLA) ranged from 13 to 39 and 12 to 55 $\mathrm{mg} \mathrm{m}^{-2}$ for cruises $352 \mathrm{~A}$ and $352 \mathrm{C}$, respectively (Figs 5C and 5D). A well-defined ICHLA core was centred around the upwelling region on cruise $352 \mathrm{C}$ with maximum higher than $50 \mathrm{mg} \mathrm{m}^{-2}$. On the other hand, during the intrusion of KSW (cruise 352A), ICHLA values were low ( $\leqslant 20 \mathrm{mg} \mathrm{m}^{-2}$ ) in the normal region of UKSW outcropping. Instead, a rather high ICHLA ( $\sim 39 \mathrm{mg} \mathrm{m}^{-2}$ ) was observed at station 23 , which was far apart from the region of ICHLA maximum (station 32) observed on cruise 352C. Distribution of surface Chla (not shown) was similar to ICHLA distribution, and the concentrations ranged from 0.1 to 1.4 and 0.1 to $1.7 \mathrm{mg} \mathrm{m}^{-3}$ for cruises $352 \mathrm{~A}$ and $352 \mathrm{C}$, respectively.

The influence of upwelled nitrate on phytoplankton biomass and productivity were investigated during cruise 386 in May 1994. Stations 1, 8, 11 and 17 can be readily assigned to three water masses according to their $T-S$ characteristics (Fig. 6A). The low salinity of station 1 represented the $\mathrm{CCW}$; the high salinity of station 17 represented the $\mathrm{KSW}$; and the intermediate salinity with relatively low temperature of stations 8 and 11 represented the upwelled UKSW (Chern and Wang, 1989; Liu et al., 1992b; Gong et al., 1995a). The depth of euphotic zone increased seaward from $20 \mathrm{~m}$ (station 1) to $55 \mathrm{~m}$ (station 17). Temperature ranged from $19^{\circ} \mathrm{C}$ (station 1) to $27^{\circ} \mathrm{C}$ (station 17) and did not change much within the euphotic zone of each station. Nitrate concentrations in the bottom of the euphotic zone ranged from undetectable $(<0.1 \mu \mathrm{M})$ to $2.5 \mu \mathrm{M}$ (Fig. $6 \mathrm{~B})$.

Surface Chla ranged from $0.2 \mathrm{mg} \mathrm{m}^{-3}$ at station 17 to $2.8 \mathrm{mg} \mathrm{m}^{-3}$ at station 1 (Fig. 6C). ICHLA for stations $1,8,11$ and 17 were $46,10,33$ and $16 \mathrm{mg} \mathrm{m}^{-2}$, respectively. The high Chl $a$ level at station 1 was caused by a bloom of athecate dinoflagellates with population densities exceeding $1 \times 10^{4}$ cells $1^{-1}$. PP profiles at these four stations all decreased exponentially with depth although the absolute values varied from station to station (Fig. 6D). The highest and lowest surface PP was observed at stations 1 and 17 with values of 134 and $11 \mathrm{mgC} \cdot \mathrm{m}^{-3} \mathrm{~d}^{-1}$, respectively. Surface PP of the upwelling stations (i.e. stations 8 and 11) showed intermediate values ranging from 30 to $93 \mathrm{mgC} \mathrm{m}^{-3} \mathrm{~d}^{-1}$. The integrated primary production for the euphotic zone at stations $1,8,11$ and 17 was $1900,430,1540$ and $420 \mathrm{mgC} \mathrm{m}^{-2} \mathrm{~d}^{-1}$, respectively.

\section{DISCUSSION}

The results indicate that, during the Kuroshio intrusion in early April 1993, the interaction between the intruding KSW and the upwelling UKSW caused changes in concentration of nitrate in the study area, which in turn changed the euphotic zone integrated Chla level. At the shelf break, the intruding KSW masked the upwelling region 

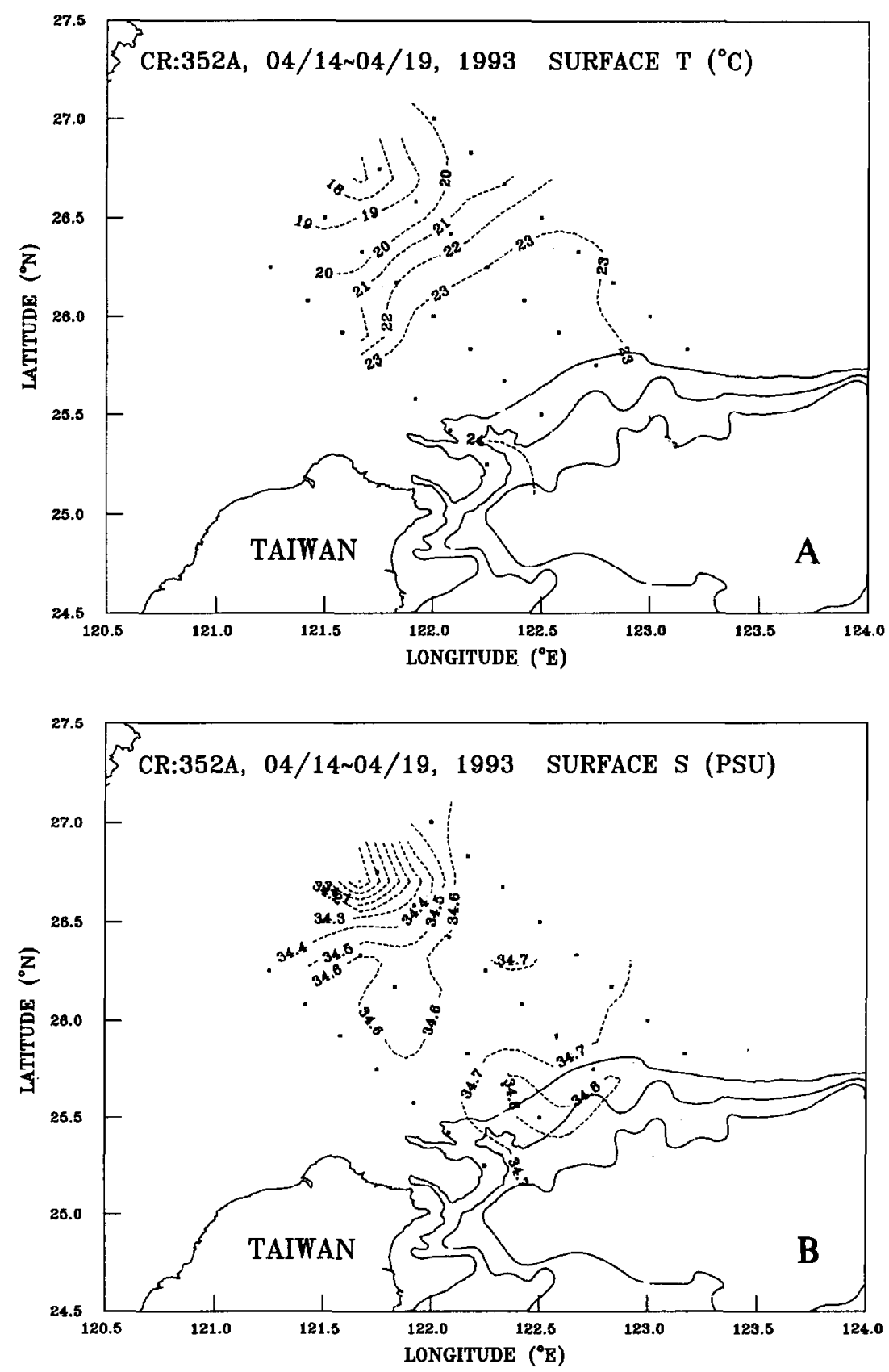

Fig. 3. Sea surface temperature and salinity (dotted) during cruises 352A and 352C. 

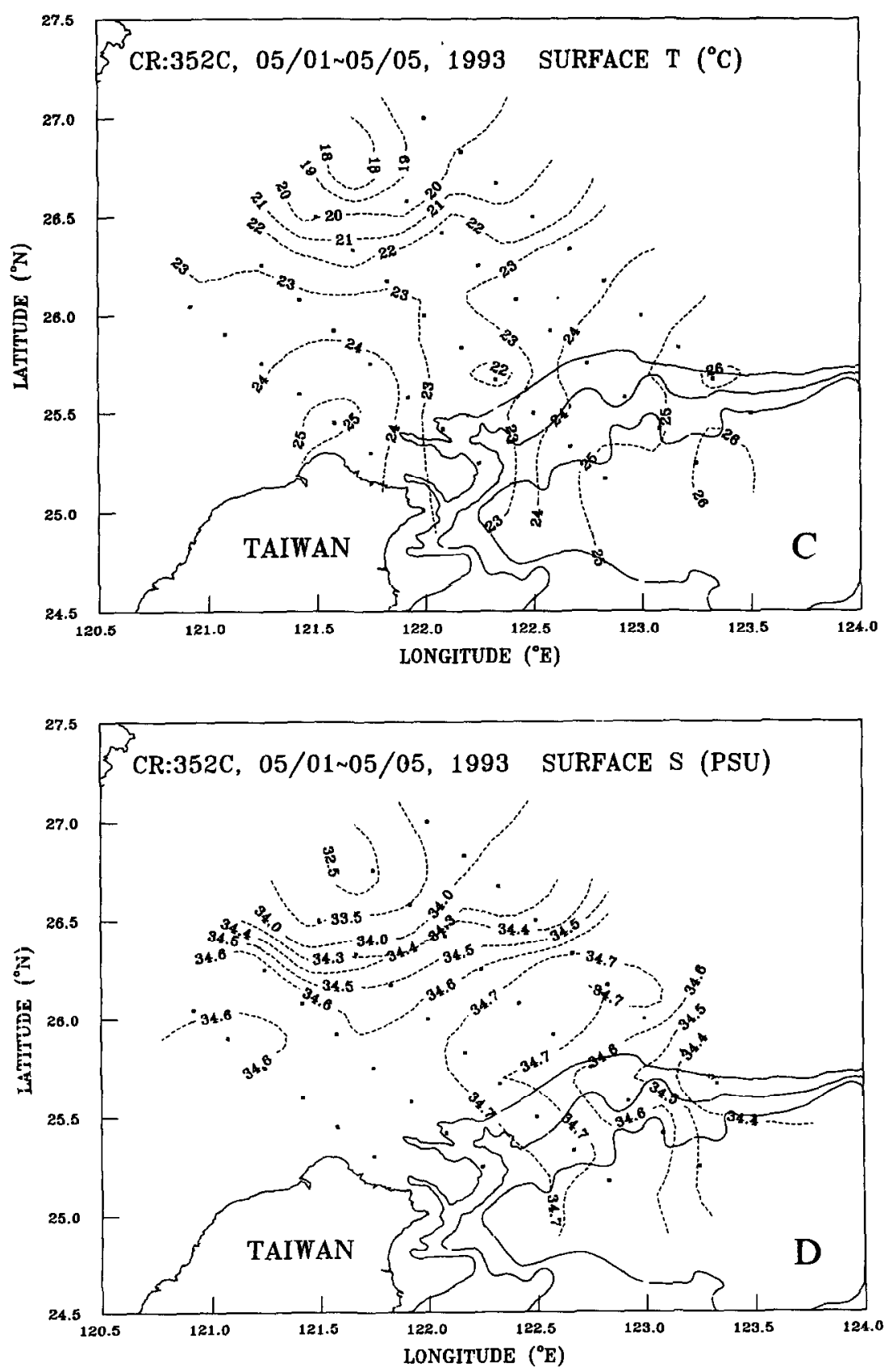

Fig. 3. (Continued) 


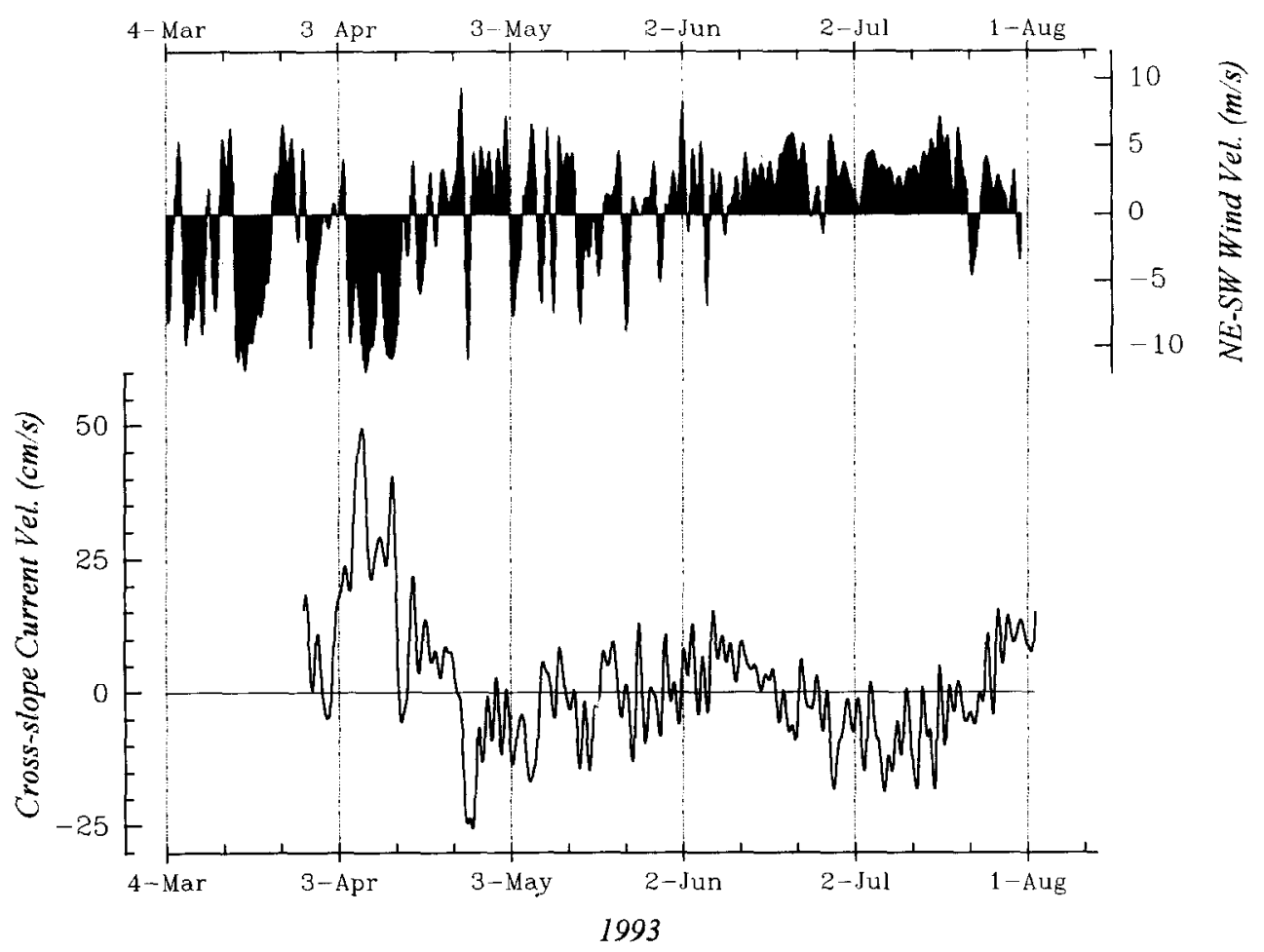

Fig. 4. Time series of wind speed and the cross-slope current velocity recorded at the depth of 110 $m$ on the shelf edge.

with low-chlorophyll, nutrient-poor, and low-density water (Figs 2A, 3A, 5A and 5C). The pool of UKSW in the subsurface layer over the outer shelf was pushed toward northwest and pressed against CCW indicated by the low temperature and low salinity around stations 37 and 38 (Figs $3 \mathrm{~A}$ and $3 \mathrm{~B}$ ). As a result, the subsurface $(50 \mathrm{~m}$ ) high nitrate water was split into two patches (Fig. 5A), which supported the development of two chlorophyll-rich centers in the overlying water (Fig. 5C). The two-patch pattern did not appear in the distribution of the sea surface temperature (Fig. 3A), because the warmer KSW overlaid the denser UKSW. In fact, KSW penetrated to the mid-shelf during intrusion and formed a strong temperature gradient against the $\mathrm{CCW}$ in the surface layer (Fig. 3A).

Starting from 23 April, the KSW intrusion started to recede (Fig. 4). Subsequently, the UKSW outcropped at the shelf break forming the characteristic patch of nutrient-enriched cold water as observed during cruise 352C (Figs 2E and 3A). High level of ICHLA was also formed around the normal upwelling region (Fig. 5D).

Nitrate concentration in the subsurface water is commonly used as an indicator of the availability of new nutrients to phytoplankton in the euphotic zone (Dugdale and Goering, 1967). In the southern East China Sea, regions with high level of nitrate at $50 \mathrm{~m}$ depth coincided well with regions of high ICHLA (Fig 5). This implies that new nitrogen is likely to be a major controlling factor of phytoplankton biomass and PP in this region. Additional 
proof came from the PP measurement during the 1994 spring cruise (cruise 386). The $T-S$ diagram indicated that waters at stations 8 and 11 both belonged to the UKSW (Fig. 6A). However, station 11 was closer to the upwelling center, as judged by the nitrate profiles (Fig. 6B). The higher Chla level and PP at station 11 was likely a result of ample nutrient supply from the upwelling (Figs 6C and 6D). A similar conclusion was drawn by Wilkerson and Dugdale (1987) for the California upwelling system.

Since the low-salinity CCW is also rich in nutrients, high ICHLA observed at stations along the north and northwest edges of the study area could be a result of CCW influence (Figs 5C and 5D). The contribution of the $\mathrm{CCW}$ to the phytoplankton growth in the study area was not as significant as that of the UKSW as observed on the cruises in 1993, because high Chla concentrations were always associated with high-salinity waters $(\sim 34.6 \mathrm{psu})$ at NW stations whereas the Chla level in the less salty $\mathrm{CCW}$ was lower. Other evidence comes from the 50-m nitrate concentrations data shown in Figs 5A and 5B. The area with nitrate concentrations $>5.0 \mu \mathrm{m}$ was occupied by the UKSW rather than CCW as indicated by the salinity ( $~-34.6 \mathrm{psu}$; Figs 3B and 5A). However, on cruise 386 in 1994, CCW indeed contained high level of Chla, but that was at a station (station 1 on transect $\mathrm{K}$ ) very close to the coast of: China (Fig. 6). The surface water had a significant nitrate concentration $(\sim 1$ $\mu \mathrm{M})$, which could have induced the intensive phytoplankton growth.

The impact of the Kuroshio intrusion on the continental shelf ecosystem can be evaluated from different angles. The upwelling has been proven as a permanent feature on the edge of the southern East China Sea north of Taiwan. With phytoplankton biomass and PP much higher than surrounding waters, the upwelling center could have been an important source of particulate organic carbon (POC) feeding the seaward flux of carbon in association with the cyclonic eddy or filament northeast of Taiwan (Chern et al., 1990; Liu et al., 1995; Ma, 1995). Its importance in cross-shelf carbon flux is currently under intensive study (Liu, 1994). By suppressing nutrient supply from the UKSW to this area, the intrusion of KSW apparently reduces phytoplankton growth at the shelf break area northeast of Taiwan. The time-integrated primary production and the associated POC export in the study area in winter might be reduced, since such intrusion must have been prevalent during the northeastern monsoon season (Lin et al., 1992; Gong, 1992; Hsueh et al., 1992; Chuang and Liang, 1994). On the other hand, the Kuroshio intrusion brought nutrient-enriched UKSW to the mid-shelf, where the water is usually nutrient-depleted (Gong et al., 1996), and increased the PP there. Consequently, the ecosystem in the mid-shelf may have benefited from the enhanced productivity caused by the intrusion.

\section{CONCLUSION}

Spatial and temporal variability of surface and euphotic zone integrated Chl $a$ concentrations and the subsurface $(50 \mathrm{~m})$ nitrate concentrations observed during four weekly cruises in Spring 1993 in the southern East China Sea north of Taiwan could be largely explained by the successions of different water masses. These included the Kuroshio surface water, the upwelled Kuroshio subsurface water, and the mainland China coastal water. The intrusion of the Kuroshio surface water suppressed the supply rate of subsurface nitrate to the euphotic zone, and thereby reduced Chla concentrations within the normal upwelling area. Outside the upwelling area, especially in the northwest of the study area, the Chl $a$ rich areas were likely to be supported by the nitrate-enriched 

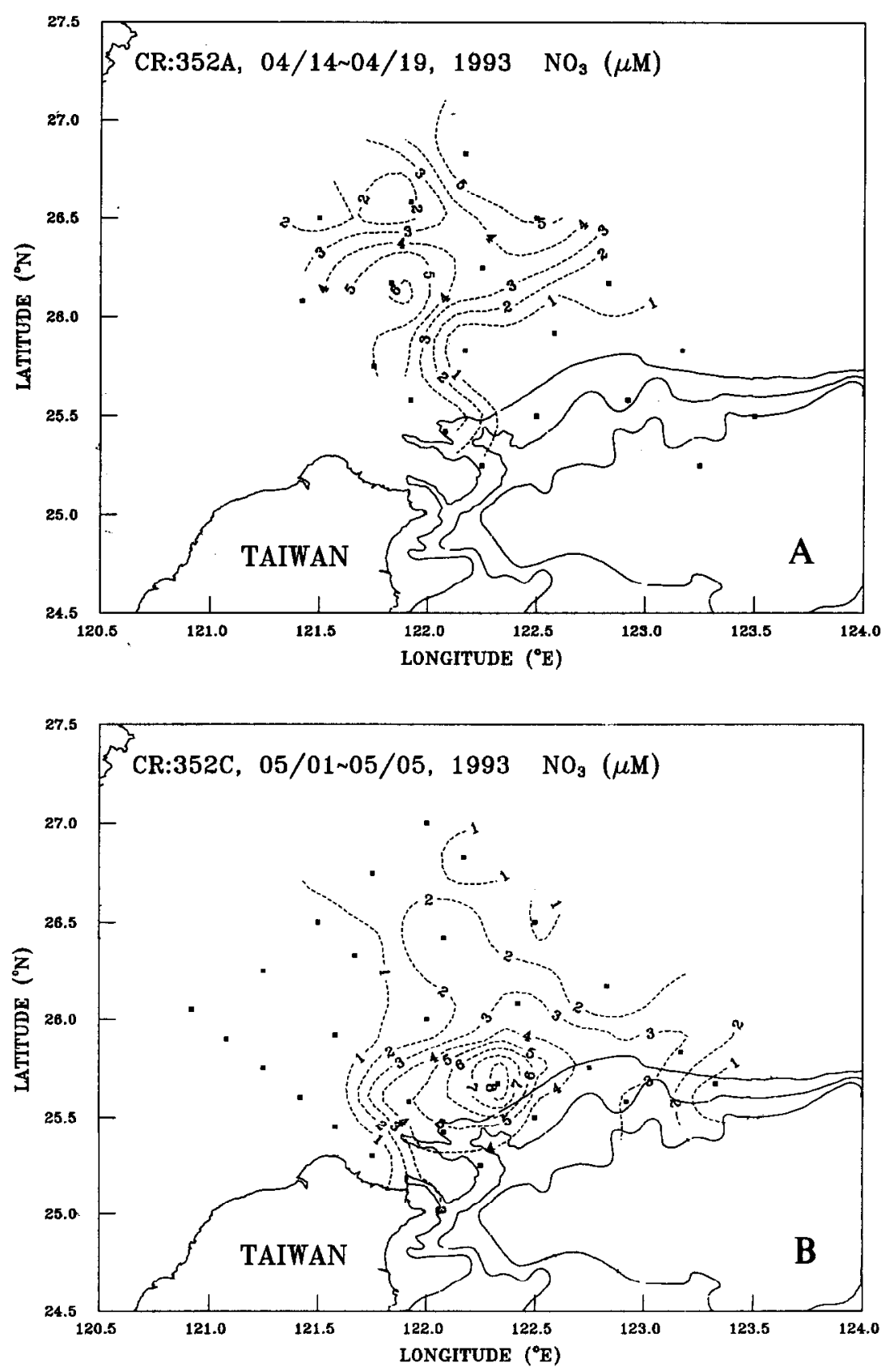

Fig. 5. Concentration of nitrate at $50 \mathrm{~m}$ and euphotic zone integrated Chla (ICHLA) during cruises $352 \mathrm{~A}$ and $352 \mathrm{C}$. 

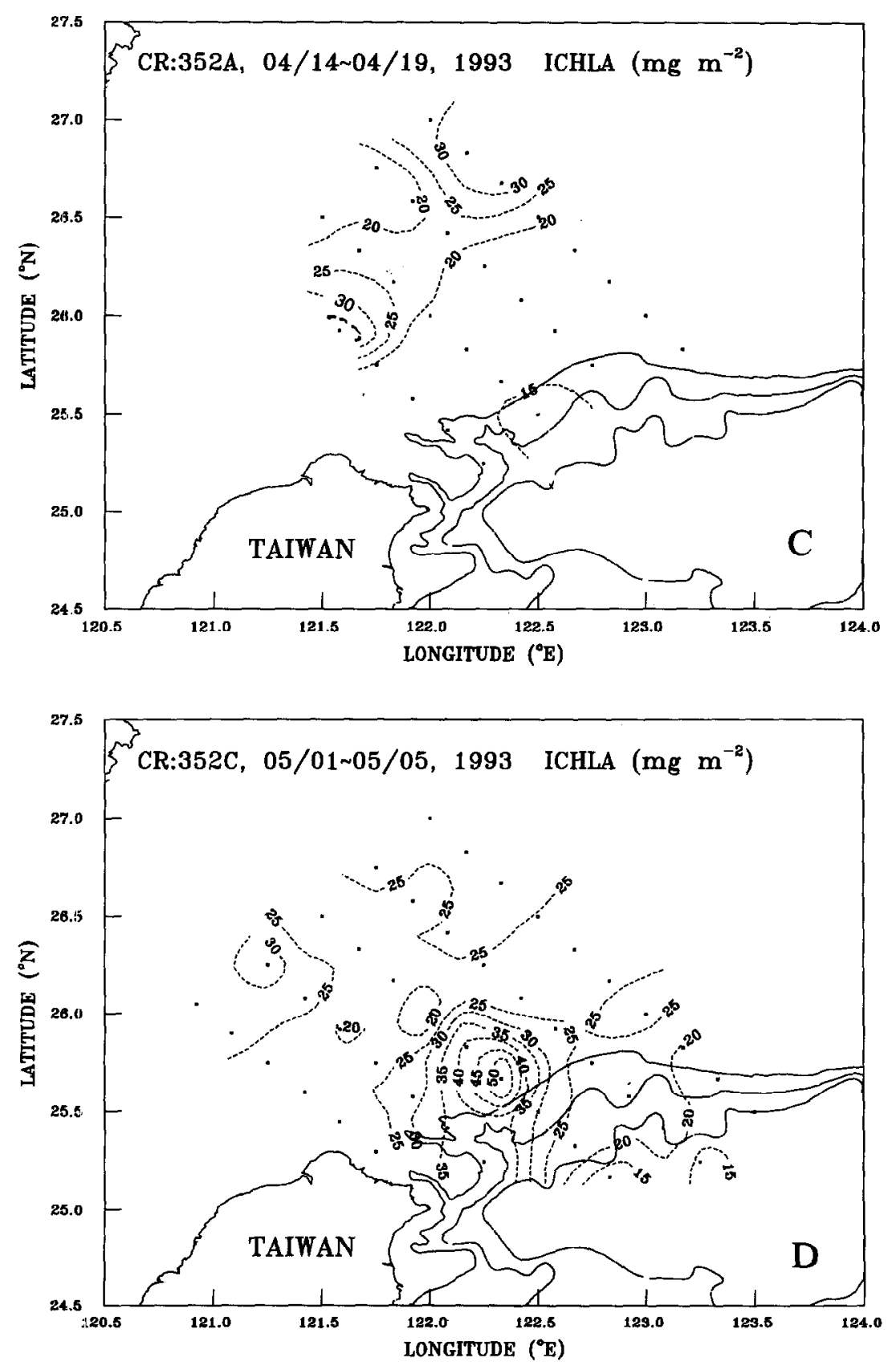

Fig. 5. (Continued) 

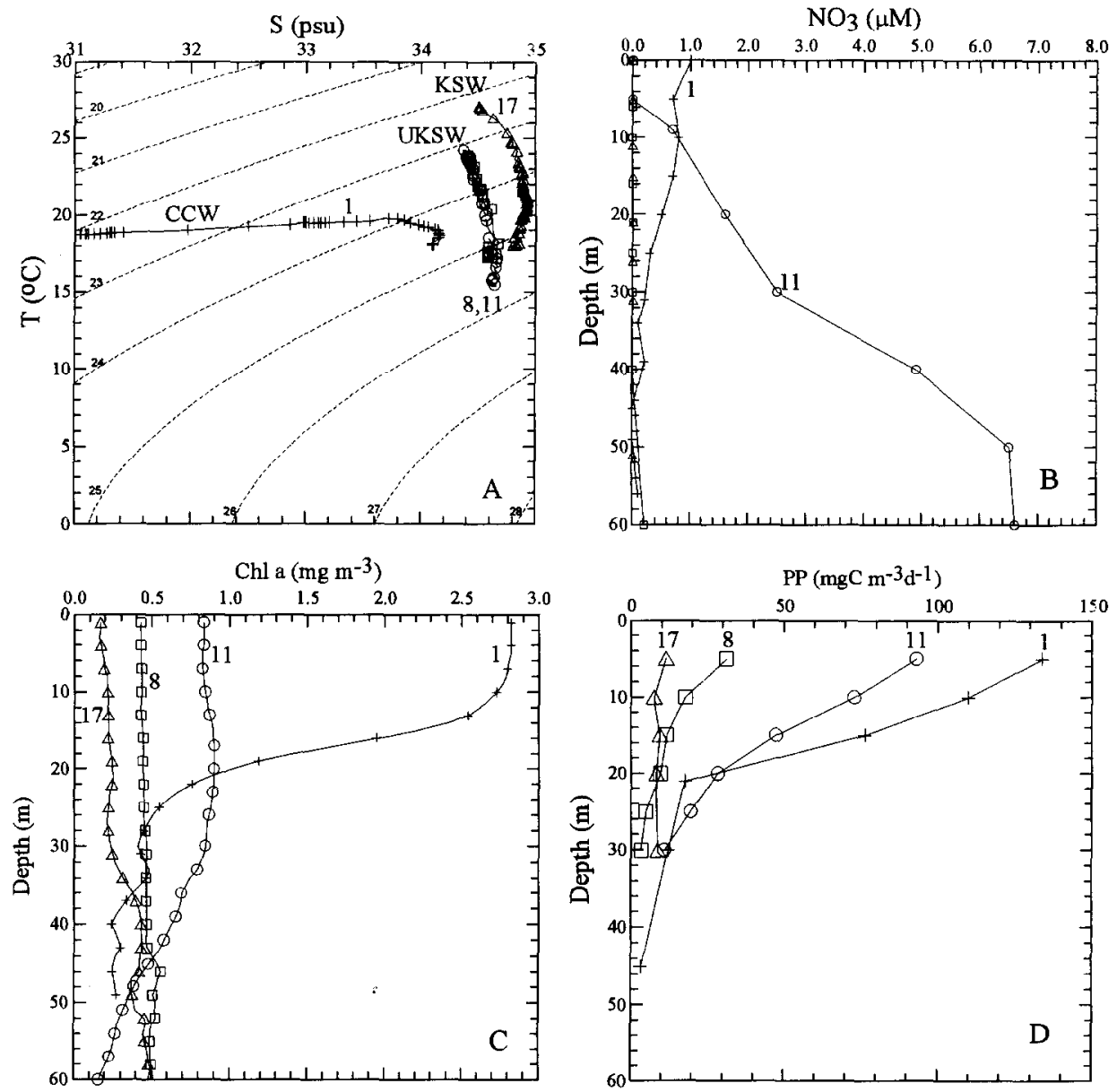

Fig. 6. Hydrographic and biological parameters on stations $1(+), 8(\square), 11(\mathrm{O})$ and $17(\triangle)$ during cruise 386: (A) temperature-salinity diagram; (B) nitrate concentrations; (C) Chla concentrations and (D) primary productivity.

upwelled Kuroshio subsurface water displaced northwestward by the Kuroshio intrusion. In May 1994, primary productivity measurement were conducted in three water masses, which were the mainland China coastal water, the Kuroshio upwelling water and the Kuroshio water. In the upwelling waters, high Chl $a$ concentration was apparently caused by the ample nitrate supply from the subsurface and enhanced primary production in the euphotic zone.

Acknowledgements-This work was supported by grants from the National Science Council (NSC), Taiwan, Republic of China from the NSC85-2611-M-019-014 K2 (GCG), NSC85-2611-M-002-005 K2 (KKL). Financial support for Dr F.-K. Shiah was provided from the NSC postdoctoral research fellowship. The authors thank Mr W.-R. Yang, Y.-H. Wen, C.-C. Leu and M.-S. Liang for their help with nutrients and chlorophyll analysis. They deeply appreciate the valuable suggestions and comments from two reviewers of this manuscript. Finally, they thank the officers and crews of R/V Oceanic Research I for cruise assistance. 


\section{REFERENCES}

Chao S.-Y. (1991) Circulation of the East China Sea, a numerical study. Journal of Oceanographical Society of Japan, 46, 273-295.

Chen Y. L. (1992) Summer phytoplankton community structure in the Kuroshio current-related upwelling northeast of Taiwan. Terrestrial, Atmospheric and Oceanic Sciences, 3, 305-320.

Chern C.-S. and J. Wang (1989) On the water masses at northern offshore area of Taiwan. Acta Oceanographica Taiwanica, 22, 14-32.

Chern C.-S. and J. Wang (1992) The influence of Taiwan Strait waters on the circulation of the southern East China Sea. La Mer, 30, 223-228.

Chern C.-S. and J. Wang (1994) Influence of the seasonal thermocline on the intrusion of Kuroshio across the continental shelf northeast of Taiwan. Journal of Oceanography, 50, 691-711.

Chern C.-S., J. Wang and D.-P. Wang (1990) The exchange of Kuroshio and East China Sea shelf water. Journal of Geophysical Research, 95, 16017-16023.

Chuang W.-S. and W.-D. Liang (1994) Seasonal variability of intrusion of the Kuroshio water across the continental shelf northeast of Taiwan. Journal of Oceanography, 50, 531-542.

Chuang W.-S., H.-W. Li, T.-Y. Tang and C.-K. Wu (1993) Observations of the countercurrent on the inshore side of the Kuroshio northeast of Taiwan. Journal of Oceanography, 49, 581-592.

Dugdale R. C. and J. J. Goering (1967) Uptake of new and regenerated forms of nitrogen in primary productivity. Limnology and Oceanography, 12, 196-206.

Fei Z., X. Mao, R. Lu, B. Li, Y. Guan, B. L. Zhang and D. Mou (1987) Distributional characteristics of chlorophyll- $a$ and primary productivity in the Kuroshio area of the East China sea. In: Essays on the investigation of Kuroshio contents, X. Sun, editor, Ocean Press, Beijing, pp. 256-266.

Gong G.-C. (1992) Chemical hydrography of the Kuroshio front in the sea northeast of Taiwan. Ph.D. Thesis, Institute of Oceanography, National Taiwan University, $204 \mathrm{pp}$.

Gong G.-C. and K.-K. Liu (1995) The relationship between surface chlorophyll $a$ and biogenic matter in the euphotic zone in the southern East Sea in spring. In: COSPAR colloquium, space remote sensing of the subtropical oceans (SRSSO), September 12-16, Taipei, Taiwan, 15A3-7.

Gong G.-C., C.-Z. Shyu, W.-H. Shiu and K.-K. Liu (1992) Temperature fluctuation of the cold eddy off northeastern Taiwan: June-December, 1990. Acta Oceanographica Taiwanica, 28, 118-127.

Gong G.-C., W.-R. Yang and Y.-H. Wen (1993) Correlation of chlorophyll $a$ concentration and Sea Tech fluorometer fluorescence in seawater. Acta Oceanographica Taiwanica, 31, 117-126.

Gong G.-C., K.-K. Liu and S.-C. Pai (1995a) Prediction of nitrate concentration from two end member mixing in the southern East China Sea. Continental Shelf Research, 15, 827-842.

Gong G.-C., W.-R. Yang and J. Chang (1995b) In vivo fluorescence-derived chlorophyll $a$ concentration in the southern East China Sea. Acta Oceanographica Taiwanica, 34, 73-85.

Gong G.-C., Y. L. Chen and K.-K. Liu (1996) Chemical hydrography and chlorophyll $a$ distribution in the East China Sea in summer: implications in nutrient dynamics. Continental Shelf Research, 16, 1561-1590.

Guo Y.-J. (1991) The Kuroshio. Part II. Primary productivity and phytoplankton. Oceanography and Marine Biology Annual Review, 29, 155-189.

Hsueh Y., J. Wang and C.-S. Chern (1992) The intrusion of the Kuroshio across the continental shelf northeast of Taiwan. Journal of Geophysical Research, 97, 14,323-14,330.

Hung T.-C., S. Lin and A. Chuang (1980) Relationships among particulate organic carbon, chlorophyll $a$ and primary productivity in the sea water along the northern coast of Taiwan. Acta Oceanographica Taiwanica, $11,70-88$.

Lin C.-Y, C.-Z. Shyu and W.-H. Shih (1992) The Kuroshio fronts and cold eddies off northeastern Taiwan observed by NOAA-AVHRR imageries. Terrestrial, Atmospheric and Oceanic Sciences, 3, 225-242.

Liu K.-K. (editor) (1994) The Taiwan-JOGFS Report, JOGFS, Taipei, China, 42 pp.

Liu K.-K., G.-C. Gong, S. Lin, C.-Z. Shyu, C.-Y. Yang, C.-L. Wei, S.-C. Pai and C.-K. Wu (1992a) The yearround upwelling at the shelf break near the northern tip of Taiwan as evidenced by chemical hydrography. Terrestrial, Atmospheric and Oceanic Sciences, 3, 234-276.

Liu K.-K., G.-C. Gong, C.-Z. Shyu, S.-C. Pai, C.-L. Wei and S.-Y. Chao (1992b) Response of Kuroshio upwelling to the onset of northeast monsoon in the sea north of Taiwan: observations and a numerical simulation. Journal of Geophysical Research, 97, 12,511-12,526.

Liu K.-K., Z.-L. Lai, G.-C. Gong and F.-K. Shiah (1995) Distribution of particulate organic matter in the 
southern East China Sea: implication in production and transport. Terrestrial, Atmospheric and Oceanic Sciences, 6, 27-45.

Ma J.-C. (1995) Currents in the sea off northern Taiwan and near the shelf break in summer. MS Thesis, Institute of Oceanography, National Taiwan University, $82 \mathrm{pp}$.

Morel A. (1988) Optical modeling of the upper ocean in relation to its biogenous matter content (Case I waters). Journal of Geophysical Research, 93, 10,749-10,768.

Parsons T. R., Y. Maita and C. M. Lalli (Eds) (1984) A manual of chemical and biological methods for seawater analysis, Pergamon, New York, p. 173.

Shiah F.-K., G.-C. Gong and K.-K. Liu (1995) A preliminary survey on primary productivity measured by the ${ }^{14} \mathrm{C}$ assimilation method in the KEEP area. Acta Oceanographica Taiwanica, 34, 1-15.

Sun X. (1987) Analysis of the surface path of the Kuroshio in the East China Sea. In: Essays on the investigation of Kuroshio, X. Sun, editor, Ocean Press, Beijing, pp. 1-14.

Tang T.-Y, and Y.-T. Yang (1993) Low frequency current variability on the shelf break northeast of Taiwan. Journal of Oceanography, 49, 193-210.

Throndsen J. (1978) Preservation and storage. In: Phytoplankton manual, A. Sournia, editor, United Nations Educational, Scientific and Cultural Organization, Paris, pp. 67-74.

Wang J. and C.-S. Chern (1988) On the Kuroshio's branching with Taiwan Strait during winter time. Progress in Oceanography, 21, 469-491.

Wang J. and C.-S. Chern (1989) On cold water intrusions in the eastern Taiwan strait during the cold season. Acta Oceanographica Taiwanica, 22, 43-67.

Wilkerson F. P. and R. C. Dugdale (1987) The use of large shipboard barrels and drifters to study the effects of coastal upwelling on phytoplankton nutrient dynamics. Limnology and Oceanography, 32, 368-382. 